\title{
Insecticide susceptibility status of the malaria vector Anopheles arabiensis in Khartoum city, Sudan: differences between urban and periurban areas
}

\author{
O.M.E. Seidahmed, ${ }^{7}$ M.A. Abdelmajed, ${ }^{2}$ M.S. Mustafa ${ }^{3}$ and A.P. Mnzava ${ }^{4}$
}

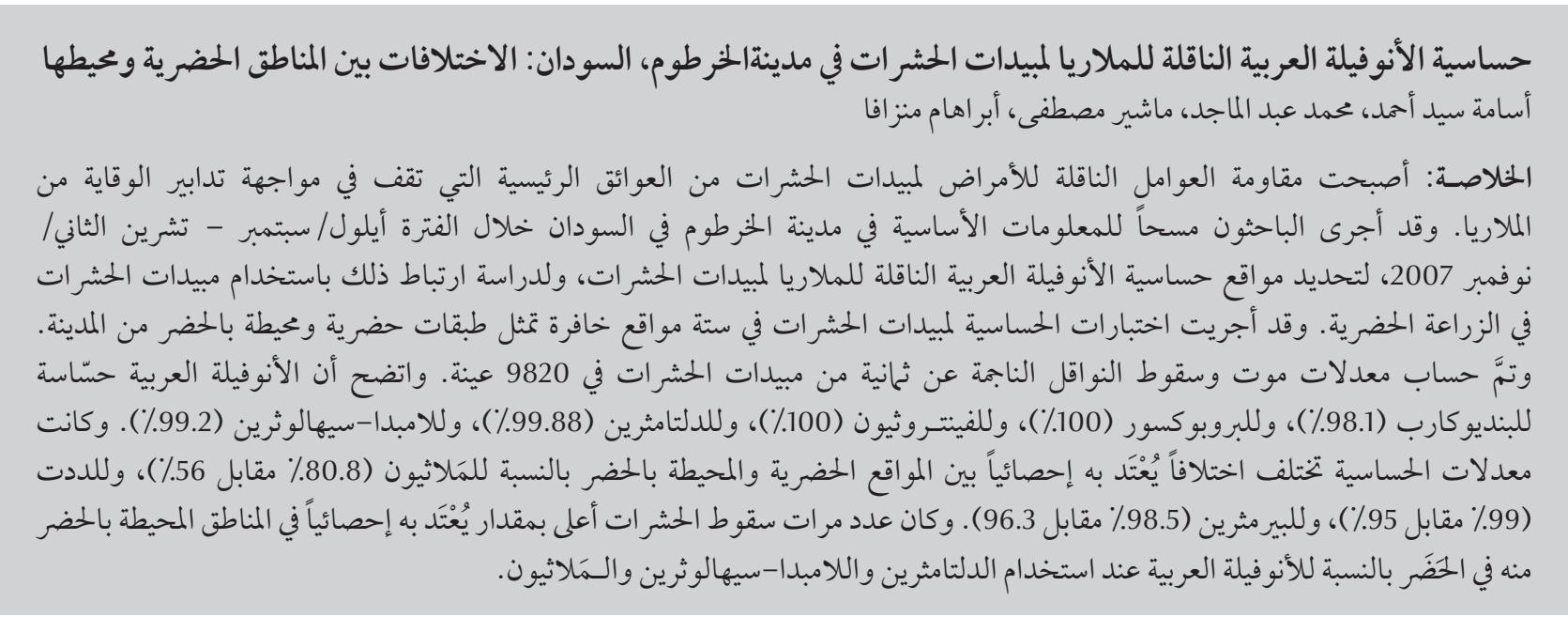

ABSTRACT Vector resistance to insecticides is becoming a major obstacle to malaria prevention measures. A baseline survey was carried out in Khartoum city, Sudan, during September-November 2007, to map the insecticide susceptibility status of Anopheles arabiensis and to examine the correlation with insecticide usage in urban agriculture. Susceptibility tests were conducted in 6 sentinel sites representing urban and periurban strata of the city. Mortality rates and knockdown times were calculated for 8 insecticides on a total of 9820 specimens. An. arabiensis was susceptible to bendiocarb (98.1\%), propoxur (100\%), fenitrothion (100\%), deltamethrin (99.8\%) and lambda-cyhalothrin (99.2\%). Susceptibility rates were significantly different between urban and periurban sites for malathion (80.8\% vs 56.0\%), DDT $(99.0 \%$ vs $95.0 \%)$ and permethrin (98.5\% vs 96.3\%). The 50\% knockdown times were significantly higher in periurban than urban populations of An. arabiensis for deltamethrin, lambda-cyhalothrin and malathion.

Sensibilité du vecteur du paludisme Anopheles arabiensis aux insecticides dans la ville de Khartoum, Soudan : différences entre les zones urbaines et périurbaines

RÉSUMÉ La résistance du vecteur aux insecticides devient un obstacle majeur à l'efficacité des mesures de prévention du paludisme. Au début de l'étude, une enquête a été menée dans la ville de Khartoum (Soudan), de septembre à novembre 2007, pour cartographier la sensibilité d'Anopheles arabiensis aux insecticides et examiner la corrélation de cette sensibilité avec l'utilisation des insecticides dans l'agriculture urbaine. Les tests de sensibilité ont été conduits sur six sites sentinelles représentant des strates urbaines et périurbaines de la ville. Les taux de mortalité et les effets de choc ont été calculés à partir de l'étude de 9820 spécimens au total et de huit insecticides. An. arabiensis était sensible au bendiocarbe $(98,1 \%)$, au propoxur (100\%), au fénitrothion (100\%), à la deltaméthrine $(99,8 \%)$ et à la lambdacyhalothrine $(99,2 \%)$. Les taux de sensibilité étaient très différents entre les sites urbains et les sites périurbains pour le malathion (80,8 \% contre 56,0 \%), le DDT (99,0 \% contre 95,0\%) et la perméthrine (98,5\% contre 96,3\%). Les effets de choc de $50 \%$ étaient nettement plus longs pour les populations d'An. arabiensis dans les zones périurbaines que dans les zones urbaines pour la deltaméthrine, la lambda-cyhalothrine et le malathion.

'Department of Medical Entomology, National Health Laboratory, Federal Ministry of Health, Khartoum, Sudan (Correspondence to O.M.E. Seidahmed: osamamekki@gmail.com). ${ }^{2}$ State Malaria Control Programme, State Ministry of Health, Khartoum, Sudan. ${ }^{3}$ Department of Biology and Chemistry, Faculty of Education, University of Gezira, Sudan and Universiti Sains Malaysia, Penang, Malaysia. ${ }^{4}$ Division of Communicable Disease Control, Vector Biology and Control, World Health Organization, Regional Office for the Eastern Mediterranean, Cairo, Egypt.

Received: 23/01/11; accepted: 13/03/11 


\section{Introduction}

Vector resistance to insecticides is becoming a major obstacle to malaria prevention measures especially in periurban ecosystems in the main cities of Africa [1]. Khartoum, the capital of Sudan, has grown from a population of 245000 in 1955 to 5.27 million in 2008 [2]. Both built-up and urban agricultural areas have expanded in response to high demand for accommodation and food. However, the relative rate of expansion varies between the city's districts, due to differences in landscape and the livelihoods of the local community [3]. Concurrently, urban agriculture has been pushed from the metropolitan zone (urban areas) to the peripheral zone (periurban areas).

Malaria constitutes a major public health problem in Khartoum, leading to about 300000 cases and 500 deaths each year on average [4]. Anopheles arabiensis is the sole malaria vector species in Khartoum [5]. The main vector control intervention in Khartoum city is larval control using Temephos ${ }^{\circ}$ EC50, with a focus of intervention activity in the urban areas of the city. Environmental management through weekly drying of irrigation canals (intermittent irrigation) is practised in the periurban areas of the city. Space spraying of insecticides and insecticide residual spraying is occasionally used when adult mosquito densities increase or when a malaria outbreak is expected. Coverage with insecticide-treated bednets is still very low in the city despite ongoing scale-up in other parts of Sudan [6].

Effectiveness of malaria vector control requires sound management of the use of insecticides to avoid or delay the development of vector resistance [7]. Elucidating the susceptibility status of local populations of An. arabiensis to insecticides is therefore essential, particularly in urban settings that may be influenced by small-scale landscape and livelihood variations. In the present study a baseline survey was carried out in Khartoum city, during the period September to November 2007, to elucidate the susceptibility status of $A n$. arabiensis to 8 different insecticides. The results were examined with respect to potential pressure of insecticide usage in urban agriculture.

\section{Methods}

\section{Study area}

Khartoum city lies within the savannah region of Sudan, characterized by a short rainy season (July to September), a short winter season (December to February) and a relatively longer summer season. Two types of study sites were selected, urban and periurban, based on the presence and magnitude of urban agriculture compared with the built-up area, and the usage of insecticides in the site. Accordingly, the following 6 sites were selected in greater Khartoum: Arkewiet and Soba West (Khartoum); Abu'siid and Essalamania West (Omdurman); Elmaygoma and Eltmanyat (Bahry).

\section{Qualitative data on urban agriculture and insecticide usage}

Qualitative data on usage of insecticides for urban agriculture were obtained from site visits, interviews, the records of the National Pesticides Council, the Sudanese Agrochemical Association, and sellers in the local market of pesticides in Khartoum city. Of all the 17 agricultural pesticides registered for use in the Sudanese market we tested the 8 insecticides recommended by WHO for use in public health and malaria control.

\section{Mosquito collection and rearing}

Mosquito specimens were collected from the field as larvae and pupae using scoops, pipettes and collection nets [8]. These were reared in trays on rice powder, and then transferred to adult cages as pupae. Emerging females and males were fed on sucrose $10 \%$ solution until they were ready for testing (1-3 days old). In accordance with World Health Organization (WHO) recommendations [9], susceptibility tests were conducted on F1 generations of larvae collected from the monitored sites. The tests were conducted in the entomology facility in the malaria department of Khartoum state.

\section{Identification and molecular work}

Polymerase chain reaction (PCR) assays in sub-samples of tested specimens ( $n=990)$, using taxonomic keys [10], confirmed identification of Anopheles arabiensis as the sole member of An. gambiae complex. PCR method was based on specific DNA nucleotide differences in the intergenic spacer of ribosomal DNA (rDNA) [11]. The identification of each An. gambiae complex specimen to the level of molecular requires 2 PCR reactions [12]. The DNA was extracted from a single mosquito using a DNA extraction kit (Qiagen) with $1 \mathrm{uL}$ of the DNA amplified in a $24 \mathrm{uL}$ PCR mix containing PCR buffer, $2.5 \mathrm{mM}$ $\mathrm{MgCl}_{2}, 0.2 \mathrm{mM}$ of each dNTP, $12.5 \mathrm{ng}$ primer UN 5 ' -GTG TGC CCC TTC CTC GAT GT-3', 6.25 ng primer AR 5'-AAG TGT CCT TCT CCA TCC TA-3', 25 ng primer QD 5'-CAG ACC AAG ATG GTT AGT AT-3', 12.5 ng primer ME 5'-TGA CCA ACC CAC TCC CTT GA-3' and 0.9 U DNA polymerase (AmpliTaq). The PCR condition with an initial step of $10 \mathrm{~min}$ at $94^{\circ} \mathrm{C}$, followed by 30 cycles each consisting of $30 \mathrm{~s}$ denaturation at $94^{\circ} \mathrm{C}, 30 \mathrm{~s}$ annealing at $50^{\circ} \mathrm{C}$ and 30 s extension at $72^{\circ} \mathrm{C}$ with the final cycle products extended for $7 \mathrm{~min}$ at $72{ }^{\circ} \mathrm{C}$. All identified specimens belonged to $A n$. arabiensis (Figure 1).

\section{Insecticide susceptibility tests}

Insecticide susceptibility tests were conducted following WHO standard procedures [13] using impregnated papers provided by WHO in March 2007. 


\section{$\begin{array}{llllllllllllllll}1 & 2 & 3 & 4 & 5 & 6 & 7 & 8 & 9 & 10 & 11 & 12 & 13 & 14 & 15 & 16\end{array}$}

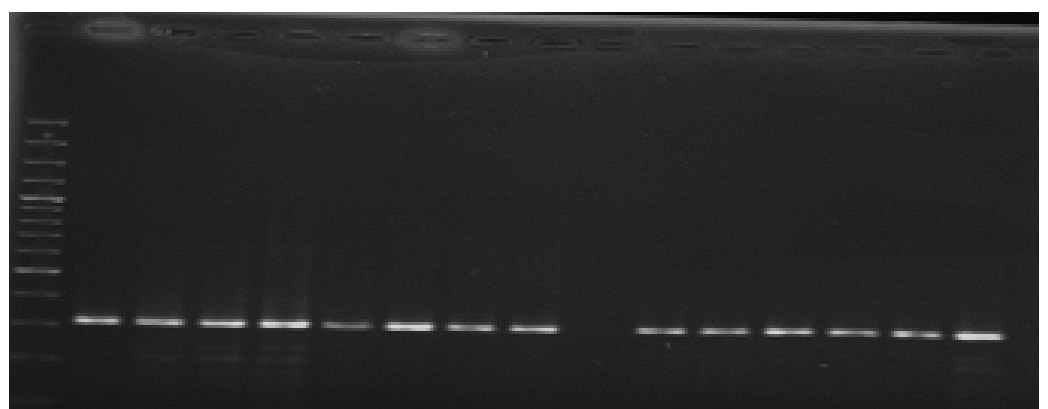

Figure 1 Two PCR assays confirm identification of Anopheles arabiensis as the sole member of An. gambiae complex in greater Khartoum. Lane 1: $100 \mathrm{~kb}$ molecular markers; lanes 2, 3, 4: Shambat and Eltamanyat samples; lanes 5, 6, 7: Soba West; lanes 8, 9: Almaygoma; lane 10: negative control; lanes 11, 12: Alhaj Yousif; lanes 13,14: Alshegalab; and lanes 15, 16: Arkewit

Insecticidal activities of the papers were confirmed by testing a sample against a reference colony of An. arabiensis (Dongola strain) previously identified as free of resistance.

Adult females and males aged 1-3 days old were tested separately by aspirating 15-25 mosquitoes each into exposure and control tubes. In each sentinel site, similar sample sizes of 100 specimens of females and males were conducted, where this was attainable.

A standard exposure time of 1 hour was used for all the tested insecticides except for fenitrothion 1.0\% for which the exposure was 2 hours. During the exposure time, the numbers of knocked down mosquitoes were recorded after 10, 15, 20, 30, 40, 50 and $60 \mathrm{~min}$. At the end of the exposure time, mosquitoes were transferred into holding tubes, provided with $10 \%$ sucrose solution and allowed a $24 \mathrm{~h}$ recovery period, after which mortality was recorded.

Control groups were composed of either adult females or males (where appropriate). These were exposed to control papers (impregnated with silicone oil, Risella oil or olive oil depending on tested insecticide group) for $1 \mathrm{~h}$ or 2 h. Temperature and relative humidity were measured during the test period using a thermohygrometer.

\section{Test conditions}

The mean ambient temperature and humidity recorded inside the laboratory at the start of the test were 26.7 [standard deviation (SD) 0.6$]^{\circ} \mathrm{C}$ and $46.4 \%$ (SD $2.4 \%)$ respectively. Similarly, the mean temperature and humidity inside the testing room after $24 \mathrm{~h}$ of the test were 27.5 (SD 0.7) ${ }^{\circ} \mathrm{C}$ and $45.7 \%$ (SD 2.2\%), respectively.

\section{Data analysis}

Mortality rates after insecticide exposure were calculated as the number of dead mosquitoes/total tested for each test replicate, where no mortality in the control replicate was found. In the case of 5\%-20\% mortality in the control group, the mortality rate of the test group was adjusted using Abbott's formula [14]. Mortality > 20\% was not observed in any of the control replicates. The mean mortality ratewas determined across all cohorts of mosquitoes tested for a particular insecticide in a specific sentinel site. Mann-Whitney analyses were used to verify whether there were significant differences between females and males, while Kruskal-Wallis tests were used to determine if there were any significant differences between sentinel sites. WHO criteria were used to evaluate the resistance/susceptibility status of the tested mosquitoes: susceptible
( $\geq 98 \%$ mortality), suspected resistance (97\%-80\% mortality) and resistance (< $80 \%$ mortality).

The exposure times to achieve 50\% and 90\% knockdown (KDT50 and KDT90) were estimated by the logtime probit model using the LdP Line software. Calculations of knockdown resistance ratio (KRR) were made with reference to the sentinel site with the shortest time. Student t-tests were conducted to compare the results from urban and periurban sentinel sites.

\section{Results}

\section{Urban agriculture and insecticide pressure in urban and periurban sites}

Table 1 presents a summary of the landscape of the study areas (geographical coordinates, types of breeding sites, population density and land use). The census from the administrative localities shows that total cultivated area in the urban sites represented 3.8\% compared with $63.5 \%$ of the total area in the periurban sites. Transformation of land usage into a built-up area was reported at 2 urban sites: Soba West and Abu'siid, where the agriculture area had decreased along the Nile banks to less than $10 \%$ of the total land area. Agriculture in periurban sites comprised large private and cooperative schemes. Field crops (wheat and maize), vegetables and fodders (clover, alfalfa and sorghum bicolour) were the main cultivated plants.

The total planted area and pesticides usage at the study sites are summarized in Table 2. It is clear from the subtotals of the insecticide concentrations that on average about $90 \%$ of the total quantities of agricultural insecticides were used in periurban sites compared with about $10 \%$ in the urban ones. The 2 organophosphates, mainly malathion, represented about $93 \%$ of the sprayed agricultural insecticide concentrations, 


\begin{tabular}{|c|c|c|c|c|c|}
\hline Area & $\begin{array}{l}\text { Geographical } \\
\text { coordinates }\end{array}$ & Main breeding sites ${ }^{a}$ & $\begin{array}{c}\text { Population } \\
\text { density }^{\mathbf{b}} \\
\left(/ \mathbf{k m}^{2}\right)\end{array}$ & $\begin{array}{c}\text { Agricultural } \\
\text { area }^{\mathrm{c}} \\
\text { (ha) }\end{array}$ & $\begin{array}{c}\text { Built-up area } \\
\text { (ha) }\end{array}$ \\
\hline Arkewit & $\begin{array}{l}15^{\circ} 53^{\prime} \mathrm{N} \\
32^{\circ} 56^{\prime} \mathrm{E}\end{array}$ & $\begin{array}{l}\text { Water tanks; indoor } \\
\text { sites; broken pipes }\end{array}$ & $>750$ & 0 & 5000 \\
\hline Soba West & $\begin{array}{l}15^{\circ} 49^{\prime} \mathrm{N} \\
32^{\circ} 67^{\prime} \mathrm{E}\end{array}$ & Reservoirs; tanks & $>750$ & 199 & 4000 \\
\hline Abu'siid & $\begin{array}{l}15^{\circ} 59^{\prime} \mathrm{N} \\
32^{\circ} 45^{\prime} \mathrm{E}\end{array}$ & Broken pipes; tanks & $>750$ & 317 & 4000 \\
\hline Elmaygoma & $\begin{array}{l}15^{\circ} 65^{\prime} \mathrm{N} \\
32^{\circ} 65^{\prime} \mathrm{E}\end{array}$ & Canals; pools & $101-250$ & 989 & 700 \\
\hline Esalamania West & $\begin{array}{l}15^{\circ} 36^{\prime} \mathrm{N} \\
32^{\circ} 45^{\prime} \mathrm{E}\end{array}$ & Canals; ditches; pools & $101-250$ & 1376 & 800 \\
\hline Eltamanyat & $\begin{array}{l}15^{\circ} 99^{\prime} \mathrm{N} \\
32^{\circ} 56^{\prime} \mathrm{E}\end{array}$ & Canals; pools; ditches & $51-100$ & 1113 & 500 \\
\hline
\end{tabular}

${ }^{a}$ Main types of breeding sites are listed according to their importance: reservoirs = reservoirs of brick-making factory; broken pipes = broken water pipelines; indoor sites = inside houses and public and private institutions; tanks = watertanks in buildings under construction; canals = leaks from irrigation canals; ditches = water ditches on riverbanks; pools = pools inside the planted area .

${ }^{b}$ Population density provided from the census of the Sudan Central Bureau of Statistics.

${ }^{c}$ Crop composition in the study sites included: vegetables (mainly potatoes, onions, egg plant, okra, tomatoes, leafy vegetables, cucumbers and spices), fruits (bananas, citrus and mangoes) and crops (sorghum, alfalfa and maize).

while pyrethroids represented $7 \%$ of the total quantities used at the study sites.

\section{Descriptive data}

The total number of tested specimens was 9820 , of which 4842 were females. Specimens were grouped into 396 exposure replicates, with 194 of these consisting of female exposures. No significant differences were observed in the mortality of males and females tested for particular insecticides, nor within each sentinel site $(P>0.05)$. The numbers of specimens tested for each insecticide in the sentinel sites are shown in Table 3. Control cohorts included 3085 specimens (151 replicates).

\section{Results of susceptibility tests}

In allareas of Khartoum citycombined, An. arabiensis was susceptible to all the tested insecticides with the exception of suspected resistance to dichlorodiphenyl-trichloroethane (DDT) (total mortality rate $96.9 \%$ ) and permethrin (97.4\%), and confirmed resistance to malathion $(69.1 \%)$ ( $\mathrm{Ta}$ ble 3). Profiles of mortality rates of tested females and males against these 3 insecticides in periurban and urban sentinel sites are shown in Figure 2.

Both male and female An. arabiensis were susceptible to DDT in all the urban sites (Table 3 ). However, some tolerance was observed for specimens from the 3 periurban sites of Eltamanyat (mean mortality rate for females 91.0\%, 95\% CI: $91.2 \%-90.8 \%$, and for males 93.0\%, 95\% CI: 93.2\%-92.8\%), Elmaygoma (mean mortality rate for females $96.0 \%$, 95\% CI: 96.1\%-95.9\% and for males 96.0\%, 95\% CI: 96.195.9\%) and Essalmanya West (mean mortality rate for females only $96.0 \%$, 95\% CI: 96.1\%-95.9\%). The tolerance of DDT correlated with usage of pyrethroids in urban agriculture in the study areas (Spearman rho $=0.88$, $P<0.05$ ).

An. arabiensis was also tolerant to permethrin in the 3 periurban sites of Elmaygoma (mean mortality rate for females 95.0\%, 95\% CI: 95.1\%$94.9 \%$ and for males $97.0 \%, 95 \% \mathrm{CI}$ : 97.1\%-96.9\%), Eltamanyat (mean mortality rate for females $96.8 \%$, 95\% CI: $98.9 \%-94.6 \%$ and for males 95.0\%, 95\% CI: 95.1\%-94.9\%) and
Essalmanya West (mean mortality rate for males only $95.0 \%, 95 \% \mathrm{CI}$ : $96.8 \%-94.6 \%)$. The tolerance of permethrin was moderately correlated with usage of pyrethroids in the study areas (Spearman rho $=0.71, P=0.11$ ).

Lower mortality rates for malathion were observed in the periurban sites (mean mortality rate 59.7\%, 95\% CI: 56.9\%-62.5\%) compared with the urban sites (mean mortality rate $80.8 \%, 95 \%$ CI: $77.8 \%-83.9 \%$ ), and the resistance was strongly correlated with agricultural usage of organophosphates in the study areas (Spearman rho $=0.91, P<0.05)$. In addition, females in the periurban areas were significantly more resistant to malathion (mean mortality rate 52.3\%, 95\% CI: $50.8 \%-53.8 \%)$ than were males (mean mortality rate $67.0 \%$, 95\% CI: 66.4\%-67.6\%) $(t=10.07 ; P$ $<0.001)$.

The resistance differences between urban and periurban areas in Khartoum were statistically significant for malathion $(t=8.57, \mathrm{df}=46, P$ $<0.001)$, DDT $(t=4.17, \mathrm{df}=31, P<$ $0.001)$ and permethrin $(t=2.03, \mathrm{df}=$ $39, P<0.05)$. 


\begin{tabular}{|c|c|c|c|c|c|c|c|}
\hline \multirow[t]{3}{*}{ Area } & \multicolumn{7}{|c|}{ Insecticide EC (dosage rate) (a,b $^{a}$} \\
\hline & \multicolumn{2}{|c|}{ Organophosphates } & \multicolumn{5}{|c|}{ Pyrethroids } \\
\hline & $\begin{array}{l}\text { Malathion } \\
57 \% \\
(4.77 \mathrm{~L} / \mathrm{ha})\end{array}$ & $\begin{array}{c}\text { Chlorpyrifos } \\
\text { (4.76 L/ha) }\end{array}$ & $\begin{array}{c}\text { Cybermethrin } \\
10 \% \\
(0.24 \mathrm{~L} / \mathrm{ha})\end{array}$ & $\begin{array}{c}\text { Deltamethrin } \\
25 \% \\
(0.36 \mathrm{~L} / \mathrm{ha})\end{array}$ & $\begin{array}{c}\text { Lambda- } \\
\text { cyhalothrin } \\
5 \% \\
(0.36 \mathrm{~L} / \mathrm{ha})\end{array}$ & $\begin{array}{c}\text { Alpha- } \\
\text { cybermethrin } \\
10 \% \\
(0.34 \mathrm{~L} / \mathrm{ha})\end{array}$ & $\begin{array}{c}\text { Permethrin } \\
10 \% \\
(0.34 \mathrm{~L} / \mathrm{ha})\end{array}$ \\
\hline \multicolumn{8}{|l|}{ Urban } \\
\hline Soba West & 429 & 0 & 17 & 9 & 9 & 5 & 4 \\
\hline Arkewiet & 0 & 0 & 0 & 0 & 0 & 0 & 0 \\
\hline Abu'siid & 232 & 0 & 9 & 5 & 5 & 3 & 2 \\
\hline Subtotal & 661 & 0 & 26 & 13 & 14 & 7 & 6 \\
\hline \multicolumn{8}{|l|}{ Periurban } \\
\hline Esalamania & 1883 & 283 & 71 & 21 & 21 & 20 & 20 \\
\hline Elmaygoma & 2621 & 393 & 98 & 30 & 30 & 28 & 28 \\
\hline Eltmanyat & 1627 & 200 & 62 & 30 & 30 & 15 & 12 \\
\hline Subtotal & 6131 & 875 & 231 & 82 & 82 & 63 & 60 \\
\hline Total & 6792 & 875 & 257 & 95 & 96 & 70 & 66 \\
\hline
\end{tabular}

${ }^{a}$ Types of pesticides and usage dosage rates were verified by retailers of the pesticides market in Khartoum city, and National Pesticides Council, Ministry of Agriculture; ${ }^{b}$ Dosage rates calculated as litres per planted hectare for each spraying cycle with respect to types of protected plants (Schumacher et al. [3]) (number of spraying cycles varied between the summer/winter seasons).

$E C=$ emulsifiable concentration.

\section{Knockdown results}

KD50 times were higher for specimens from periurban sites compared with urban sites for deltamethrin $(t=$ $2.71, \mathrm{df}=45, P<0.001)$ and lambdacyhalothrin $(t=3.96, \mathrm{df}=46, P<$
0.001) (Table 4). Similarly, the KRR of malathion was around 1.6-fold higher in periurban sites compared with the most

\begin{tabular}{|c|c|c|c|c|c|c|c|c|}
\hline \multirow[t]{2}{*}{ Site } & \multicolumn{8}{|c|}{ Mean mortality rate (\%) } \\
\hline & $\begin{array}{c}\text { Bendiocarb } \\
1.0 \%\end{array}$ & $\begin{array}{l}\text { DDT } \\
4 \%\end{array}$ & $\begin{array}{c}\text { Deltamethrin } \\
0.05 \%\end{array}$ & $\begin{array}{c}\text { Fenitrothion } \\
\mathbf{1 . 0} \%\end{array}$ & $\begin{array}{l}\text { Lambda- } \\
\text { cyhalothrin } \\
0.05 \%\end{array}$ & $\begin{array}{l}\text { Malathion } \\
\quad 5.0 \%\end{array}$ & $\begin{array}{c}\text { Permethrin } \\
0.75 \%\end{array}$ & $\begin{array}{c}\text { Propoxur } \\
0.1 \%\end{array}$ \\
\hline \multicolumn{9}{|l|}{ Urban } \\
\hline Abu'siid & $\begin{array}{c}98.5 \\
(100: 100)\end{array}$ & $\begin{array}{c}99.0 \\
(100: 100)\end{array}$ & $\begin{array}{c}100 \\
(100: 100)\end{array}$ & $\begin{array}{c}100 \\
(100: 100)\end{array}$ & $\begin{array}{c}99.0 \\
(100: 100)\end{array}$ & $\begin{array}{c}76.0 \\
(100: 100)\end{array}$ & $\begin{array}{c}100 \\
(100: 100)\end{array}$ & $\begin{array}{c}100 \\
(100: 100)\end{array}$ \\
\hline Arkweit & $\begin{array}{c}97.7 \\
(100: 200)\end{array}$ & $\begin{array}{c}99.0 \\
(100: 100)\end{array}$ & $\begin{array}{c}100 \\
(100: 100)\end{array}$ & $\begin{array}{c}100 \\
(100: 100)\end{array}$ & $\begin{array}{c}98.8 \\
(100: 100)\end{array}$ & $\begin{array}{c}78.0 \\
(100: 100)\end{array}$ & $\begin{array}{c}98.4 \\
(100: 100)\end{array}$ & $\begin{array}{c}100 \\
(100: 100)\end{array}$ \\
\hline Soba West & $\begin{array}{c}98.3 \\
(100: 165)\end{array}$ & $\begin{array}{c}99.0 \\
(100: 112)\end{array}$ & $\begin{array}{c}100 \\
(100: 100)\end{array}$ & $\begin{array}{c}100 \\
(100: 100)\end{array}$ & $\begin{array}{c}99.5 \\
(100: 100)\end{array}$ & $\begin{array}{c}85.5 \\
(100: 100)\end{array}$ & $\begin{array}{c}99.5 \\
(100: 100)\end{array}$ & $\begin{array}{c}100 \\
(114: 100)\end{array}$ \\
\hline \multicolumn{9}{|l|}{ Periurban } \\
\hline Elmaygoma & $\begin{array}{c}99.0 \\
(100: 100)\end{array}$ & $\begin{array}{c}96.0 \\
(100: 100)\end{array}$ & $\begin{array}{c}99.5 \\
(105: 100)\end{array}$ & $\begin{array}{c}100 \\
(100: 100)\end{array}$ & $\begin{array}{c}98.9 \\
(100: 95)\end{array}$ & $\begin{array}{c}61.0 \\
(107: 100)\end{array}$ & $\begin{array}{c}96 \\
(100: 100)\end{array}$ & $\begin{array}{c}100 \\
(100: 100)\end{array}$ \\
\hline Eltmanyat & $\begin{array}{c}98.5 \\
(100: 100)\end{array}$ & $\begin{array}{c}92.0 \\
(100: 100)\end{array}$ & $\begin{array}{c}99.5 \\
(100: 100)\end{array}$ & $\begin{array}{c}100 \\
(100: 86)\end{array}$ & $\begin{array}{c}99.5 \\
(100: 100)\end{array}$ & $\begin{array}{c}59.5 \\
(100: 100)\end{array}$ & $\begin{array}{c}95.9 \\
(100: 100)\end{array}$ & $\begin{array}{c}100 \\
(100: 100)\end{array}$ \\
\hline $\begin{array}{l}\text { Essalamania } \\
\text { West }\end{array}$ & $\begin{array}{c}97.5 \\
(100: 100)\end{array}$ & $\begin{array}{c}97.0 \\
(100: 100)\end{array}$ & $\begin{array}{c}100 \\
(100: 100)\end{array}$ & $\begin{array}{c}100 \\
(100: 96)\end{array}$ & $\begin{array}{c}100 \\
(100: 100)\end{array}$ & $\begin{array}{c}58.5 \\
(100: 118)\end{array}$ & $\begin{array}{c}98.0 \\
(100: 100)\end{array}$ & $\begin{array}{c}100 \\
(116: 100)\end{array}$ \\
\hline Total & $\begin{array}{c}98.1 \\
(1365)\end{array}$ & $\begin{array}{l}96.9 \\
(1212)\end{array}$ & $\begin{array}{l}99.8 \\
(1211)\end{array}$ & $\begin{array}{c}100 \\
(1182)\end{array}$ & $\begin{array}{l}99.23 \\
(1195)\end{array}$ & $\begin{array}{c}69.1 \\
(1225)\end{array}$ & $\begin{array}{c}97.4 \\
(1200)\end{array}$ & $\begin{array}{c}100 \\
(1230)\end{array}$ \\
\hline
\end{tabular}

Figures in parentheses (F:M) are numbers offemale and male mosquitoes exposed: mortality rate per site was calculated as a mean of males and females. MannWhitney and Kruskal-Wallis tests showed no significant difference between females and males $(P>0.05)$, and between sentinel sites $(P>0.05)$.

$D D T=$ dichloro-diphenyl-trichloroethane. 


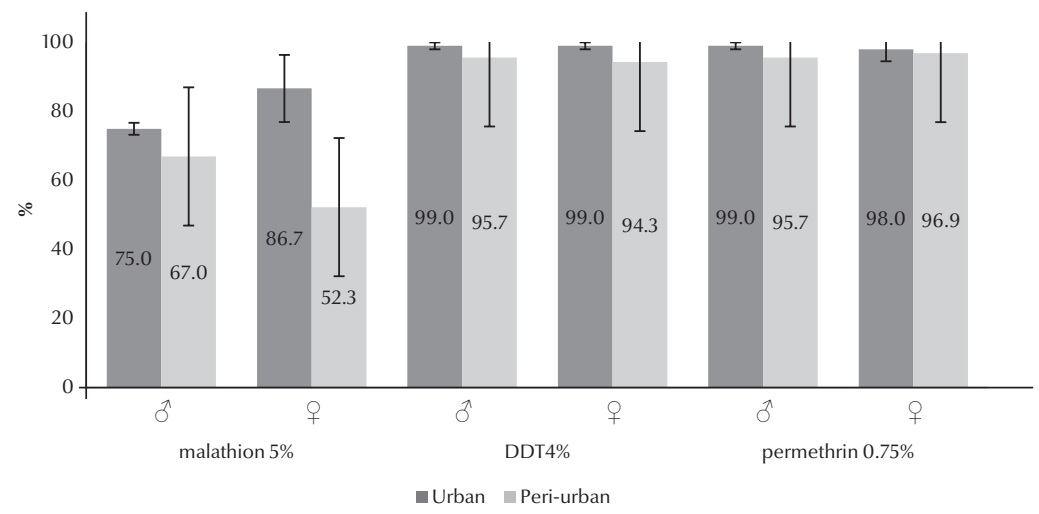

Figure 2 Mortality rates of Anopheles arabiensis from urban and periurban areas of Khartoum city after exposure to malathion (5.0\%), dichloro-diphenyl-trichloroethane (DDT) $(4.0 \%)$, and permethrin $(0.75 \%)$ in World Health Organization insecticide susceptibility tests

susceptible urban site $(t=6.25, \mathrm{df}=44$, $P<0.001)($ Table 5).

\section{Discussion}

Development of urban agriculture in Khartoum city has coincided with increasing use of insecticides in periurban areas compared with urban ones, where agriculture practices for the latter are now halted or diminished. In this study no chemical analyses for residues of insecticides in the breeding containers were done. However, it was apparent there was an impact of agricultural pesticides on susceptibility of Anopheles spp., as shown by differences in the insecticide susceptibility of these populations in agricultural periurban areas and nonagricultural urban ones.

According to the WHO criteria for insecticide susceptibility, evidence for resistance to malathion in An. arabiensis in Khartoum city was identified. In addition, suspected resistance to DDT and permethrin was also reported for An. arabiensis from periurban areas of Khartoum. On the other hand, An. arabiensis in urban areas was susceptible to malathion, DDT and permethrin. In addition, significant differences in knockdown rates between periurban and urban sites were observed for malathion and other 2 pyrethroids. In Nigeria and Ghana, Kristan et al. observed slight differences in the urban/ periurban distributions of anopheline fauna and pyrethroid molecular resistance [15].

The results reported here for malathion agree with both historical and recent studies from neighbouring

\begin{tabular}{|c|c|c|c|c|c|c|}
\hline Insecticide/area & $\begin{array}{c}\text { KDT50 }(95 \% \mathrm{Cl}) \\
(\mathrm{min})\end{array}$ & Index & KRR & $\begin{array}{l}\text { KDT9 } \\
(\mathrm{min})\end{array}$ & $t$-test & $P$-value \\
\hline \multicolumn{7}{|l|}{ Deltamethrin $0.5 \%$} \\
\hline Urban & $15.1(14.7-15.6)$ & 100.0 & 1 & 28.6 & \multirow[t]{2}{*}{2.71} & \multirow[t]{2}{*}{0.002} \\
\hline Periurban & $18.2(16.5-20.0)$ & 83.0 & 1.20 & 29.8 & & \\
\hline \multicolumn{7}{|c|}{ Lambda-cyhalothrin $0.05 \%$} \\
\hline Urban & $20.6(19.1-22.2)$ & 100.0 & 1 & 33.2 & \multirow[t]{2}{*}{3.96} & \multirow[t]{2}{*}{$<0.001$} \\
\hline Periurban & $24.3(23.2-25.4)$ & 84.8 & 1.18 & 37.9 & & \\
\hline \multicolumn{7}{|l|}{ Permethrin $0.75 \%$} \\
\hline Urban & $22.9(21.6-24.3)$ & 93.8 & 1.07 & 37.5 & \multirow[t]{2}{*}{1.24} & \multirow[t]{2}{*}{0.22} \\
\hline Periurban & 21.7 (19.7-23.8) & 100.0 & 1 & 41.7 & & \\
\hline \multicolumn{7}{|l|}{ DDT $4 \%$} \\
\hline Urban & $35.4(33.4-37.5)$ & 94.1 & 1.06 & 56.0 & \multirow[t]{2}{*}{1.45} & \multirow[t]{2}{*}{0.154} \\
\hline Periurban & $33.4(31.4-35.4)$ & 100.0 & 1 & 60.1 & & \\
\hline
\end{tabular}

$K D T 50=$ exposure time for $50 \%$ knockdown; $K D T 90=$ exposure time for $90 \%$ knockdown; $C I=$ confidence interval; index $=$ the comparative potency index calculated with reference to the lowest $K D T 50$ for the type of insecticide; $K R R=$ knockdown resistance ratio calculated with reference to the lowest $K D T 50$ for the type of insecticide; $D D T=$ dichloro-diphenyl-trichloroethane. 
Gezira state $[16,17]$. However, there is no evidence that malathion resistance is geographically widespread. Based on the reported use of malathion in agriculture [17], resistance is likely to be influenced by land use in periurban parts of Khartoum where there is no aerial spraying of malathion in vector control. In contrast, Lines had argued that in the irrigated scheme in Gezira, malathion resistance was attributed to house spraying rather than aerial crop spraying [16].

The susceptibility pattern of An. arabiensis to pyrethroids in Khartoum is inconsistent with recent reports from neighbouring Gezira and Sennar states $[17,18]$, where An. arabiensis was reported to be resistant to deltamethrin. It should be noted, however, that there is evidence of use of large quantities of pesticides in agriculture for a long time now in both Gezira and Sennar states. The use of pyrethroids in periurban areas of Khartoum for vegetable farming may be a more recent phenomenon, as confirmed by high knockdown times of deltamethrin and lambda-cyhalothrin from this study.
In this study, no molecular work was conducted to detect either the presence of knockdown resistance mutations or markers of metabolic resistance. Recent studies in Sudan have reported the occurrence of the 2 knockdown resistance mutations (Leu-Phe and Leu-Ser) in An. arabiensis populations $[17,19]$. Further molecular work is needed to explore the possibility of development of multi-resistance patterns of vectors in the city as a result of urban agriculture.

A case study has shown that farmers in Khartoum rely heavily on chemical control for crop protection. The reported misuse of insecticides by farmers is thought to be due to a lack of appropriate cultural practices as well as poor knowledge on pesticide hazards and safety precautions [20]. It is therefore recommended that future studies on insecticide resistance in Sudan should be linked to land use by the community so as not to miss out potential areas under insecticide selection pressure.

In conclusion, strengthened intersectoral collaboration between the agricultural and public health departments is recommended to monitor and manage the impact of the growing market and usage of agricultural pesticides on the emergence of vector resistance. This will ensure that the few arsenals of weapons available for vector control are appropriately preserved.

\section{Acknowledgements}

Dr I. Bakr provided the LdP Line software for estimating the knockdown rates. The mosquito surveillance team of the malaria control programme of Khartoum state, in particular Hassan, Gasim, Mahmood and Jalal, collected the field samples. Ahlam Hassan (National Council of Pesticides), Esmat Elhashimi (Sudanese Associations for Chemicals of Agriculture) and retailers of local pesticides companies are thanked for their assistance. Hilary Ranson provided useful comments to improve the manuscript, while Tessa Knox constructively criticized the layout and clarified the language. We are grateful to all of them.

\section{References}

1. Matthys B et al. Urban farming and malaria risk factors in a medium-sized town in Cote d'Ivoire. American Journal of Tropical Medicine and Hygiene, 2006, 75:1223-1231.

2. Fifth Sudan population and housing census-2008: priority results. Sudan Central Bureau of Statistics [online] (http://www. cbs.gov.sd, accessed 31 May 2012).

3. Schumacher $\mathrm{J}$ et al. Spatial expansion and water requirements of urban agriculture in Khartoum, Sudan. Journal of Arid Environments, 2009, 73:399-406.

4. Malik EM et al. Stratification of Khartoum urban area by the risk of malaria transmission. Eastern Mediterranean Health Journal., 2003, 9:559-569.

5. Petrarca $\vee$ et al. Cytogenetics of the Anopheles gambiae complex in Sudan, with special reference to An. arabiensis: relationships with East and West African populations. Medical and Veterinary Entomology, 2000, 14:149-164.

6. Onwujekwe $\mathrm{O}$ et al. Socio-economic inequity in demand for insecticide-treated nets, indoor residual house spraying, larviciding and fogging in Sudan. Malaria Journal, 2005, 4:62.

7. The work of the African Network on Vector Resistance to Insecticides, 2000-2004. Geneva, World Health Organization, 2005.
8. Entomological field techniques for malaria control. Part 1. Geneva, World Health Organization, 1992:77.

9. Guidelines for testing mosquito adulticides for indoor residual spraying and treatment of mosquito nets. Geneva, World Health Organization, 2006 (WHO/CDS/NTD/WHOPES/ GCDPP/2006.3).

10. Gillies MT, De Meillon B. The Anophelinae of Africa south of the Sahara. Johannesburg, South African Institute for Medical Research, 1968:54.

11. Scott JA, Brogdon WG, Collins FH. Identification of single specimens of the Anopheles gambiae complex by the polymerase chain reaction. American Journal of Tropical Medicine and Hygiene, 1993, 49:520-529.

12. Fanello C, Santolamazza F, della Torre A. Simultaneous identification of species and molecular forms of the Anopheles gambiae complex by PCR-RFLP. Medical and Veterinary Entomology, 2002, 16:461-464.

13. Techniques to detect insecticide resistance mechanisms (field and laboratorymanual). Geneva, World Health Organization, 1998 (WHO/CDC/CPC/MAL/98.6).

14. Abbott WS. A method of computing the effectiveness of an insecticide. Journal of Economic Entomology, 1925, 18:265-267. 
15. Kristan $\mathrm{M}$ et al. Pyrethroid resistance/susceptibility and differential urban/rural distribution of Anopheles arabiensis and An. gambiae s.s. malaria vectors in Nigeria and Ghana. Medical and Veterinary Entomology, 2003, 17:326-332.

16. Lines JD. Do agricultural insecticides select for insecticide resistance in mosquitoes? A look at the evidence. Parasitology Today, 1988, 4:S17-S20.

17. Abdalla $\mathrm{H}$ et al. Insecticide susceptibility and vector status of natural populations of Anopheles arabiensis from Sudan. Transactions of the Royal Society of Tropical Medicine and Hygiene, 2008, 102:263-271.
18. Matambo TS et al. Insecticide resistance in Anopheles arabiensis and association with the kdr mutation. Medical and Veterinary Entomology, 2007, 21:97-102.

19. Himeidan YE et al. Short report: permethrin and DDT resistance in the malaria vector Anopheles arabiensis from eastern Sudan. American Journal of Tropical Medicine and Hygiene, 2007, 77:1066-1068.

20. Ahmed IE. A case study of possible causes of insecticides misuse in fruit and vegetable production in Khartoum state [Master's thesis]. Khartoum, Sudan, Faculty of Agriculture, University of Khartoum, 2004.

\section{Evolving threat of antimicrobial resistance (The)}

Antimicrobial resistance (AMR) is not a recent phenomenon, but it is a critical health issue today. Over several decades, to varying degrees, bacteria causing common infections have developed resistance to each new antibiotic, and AMR has evolved to become a worldwide health threat. With a dearth of new antibiotics coming to market, the need for action to avert a developing global crisis in health care is increasingly urgent.

The World Health Organization has long recognized AMR as a growing global health threat, and the World Health Assembly, through several resolutions over two decades, has called upon Member States and the international community to take measures to curtail the emergence and spread of AMR. The WHO Global strategy for the containment of antimicrobial resistance, published in 2001, set out a comprehensive set of recommendations for AMR control which remain valid today. The evolving threat of antimicrobial resistance examines the experiences with implementing some of those recommendations ten years on, the lessons learnt along the way and the remaining gaps.

Further information about this and other WHO publications is available at: http://www.who.int/publications/en/ 